\title{
Misioneros flamencos en América Latina
}

\author{
WERNER THOMAS *
}

En la primavera de 1519 un ejército de aventureros españoles de unos quinientos hombres dirigido por Hernán Cortés desembarcó en las costas de Méjico. En apenas año y medio este grupo reducido derribó el poderoso imperio de los Aztecas. La conquista militar se acompañó de una conquista de las almas. Pronto Cortés suplicó al emperador Carlos V le mandase misioneros para emprender la evangelización de los indios. Unos cuantos franciscanos, mucho menos numerosos que los soldados de Cortés, bautizarian en los primeros años después de la caída de Tenochtitlán a cientos de miles de indios e iniciarían su enseñanza en la religión católica. El trabajo que estos medicantes realizaron en la primera fase de la cristianización de América resulta aún más impresionante que los efectos de la atrevida expedición de Cortés. La mayoria de los franciscanos procedía de la metrópoli. Los primeros en pisar tierra mejicana, sin embargo, no eran españoles. Eran tres flamencos que despertaron la envidia apenas escondida de varios cronistas españoles, como Mendieta y Oviedo: Jan Dekkers, Jan Auwera y Pieter van Gent, mejor conocidos como Juan de Tecto, Juan Aora y Pedro de Gante. Precisamente ellos realizarian un trabajo importante de pioneros en la evangelización del Nuevo Mundo.

\section{TRAS COLÓN}

Sin embargo, la primera presencia de religiosos flamencos en América data de mucho antes de la conquista de Cortés. Ya en septiembre de 1493 los franciscanos Jean de la Deule y Jean Cosin acompañaron a Colón en su segundo viaje al continente recién descubierto. Se cree que

\footnotetext{
* Universidad de Lovaina.
} 
De la Deule nació alrededor de 1460 en Picardia, en aquel entonces provincia de los Países Bajos borgoñeses. Desde 1481 residía en el monasterio de los observantes de Ath en el condado de Henao. Cosin era probablemente también picardo y procedía del mismo convento.

De hecho no era la intención de los Reyes Católicos permitir que religiosos extranjeros participasen en la segunda expedición de Colón. Ya habían confiado al aragonés fray Bernardo Boil el mando de tres franciscanos castellanos y otros tantos mercedarios. Isabel y Fernando aprovecharon el Capítulo General de los franciscanos, que se celebró en Florensac a fines de mayo de 1493, para obtener la licencia del vicario general Olivier Maillard. A la vuelta del capitulo Maillard y un tal fray Vicente de Ostende divulgaron las noticias del descubrimiento colombino. De la Deule y Cosin decidieron, con licencia de Maillard, viajar a la península Ibérica y embarcar para América. Como no formaban parte del grupo anteriormente escogido, se los mandó al reino de Granada, donde al arzobispo Talavera organizaba la implantación de la fe católica entre los moriscos. No hablaban árabe y por tanto le fueron de poca utilidad. Al final consiguieron el permiso de embarcar con Colón.

La flota ganó Hispaniola a fines de noviembre de 1493. Mientras Colón prosiguió su búsqueda de tierra desconocida, los dos flamencos acompañaron al jerónimo catalán Ramón Pané al sur de la isla para iniciar la evangelización de los tribus. Los indios, sin embargo, les ahuyentaron y el trío tuvo que trasladarse a la costa occidental. A pesar de que sus conocimientos de los idiomas indígenas no eran suficientes, hicieron un trabajo de gran mérito, hasta tal punto que Bartolomé de las Casas, que conocía por lo menos a De la Deule personalmente, los alabó en su Apologética Historia Sumaria. Los describió como hombres «muy bien sabidos y letrados", a diferencia de Pané, que calificó como hombre simple de buena voluntad pero con pocas calidades.

Mientras los otros religiosos habian vuelto a España, Boil ya lo habia hecho antes. Temiendo que sus esfuerzos se anularan si no venian refuerzos de Europa y viendo que Colón tardó en empezar con la evangelización sistemática de las Antillas, los flamencos decidieron en 1499 volver a España para alistar nuevos misioneros. Para convencer a posibles candidatos se llevaron a dos indios, uno de los cuales murió durante el viaje. Al llegar se entrevistaron con Maillard, que una vez más insistió a los Reyes Católicos en que organizasen una nueva expedición de observantes a Hispaniola. Ya en la primavera de 1500 los flamencos volvieron con cuatro franciscanos, probablemente muy a disgusto de Colón. Una de las últimas noticias de los dos flamencos la constituye una carta dirigida a los Reyes en octubre de 1500 , en la cual critican a los hermanos 
Colón, sumándose a las numerosas quejas cursadas contra ellos desde 1499. El cardenal Cisneros accedió a las múltiples súplicas y mandó en 1502 a un grupo de doce observantes. Es probable que los dos flamencos los acogieran y les informaran de la situación local, aunque no se dispone de pruebas. De la Deule habría muerto entre 1508 y 1511, quizás durante su trabajo misionero en Jamaica. Cosin aparece en 1514 como Protector de los indios al lado de Diego Velázquez, gobernador de Cuba. Posteriormente no existe otro indicio.

\section{VETO REAL}

Parece que entre 1502 y la coronación del duque Carlos como rey de España en 1517, ningún religioso flamenco haya hecho la travesía a las Antillas. Es verdad que Isabel y Fernando se apoyaban cada vez más en la cláusula de la bulas alejandrinas de 1493 para impedir el embarque de extranjeros sin su permiso. Sin embargo, estas cláusulas no se extendían a las personas religiosas. Casi siempre era necesario completar las expediciones con buen número de religiosos extranjeros, ya que a los provinciales españoles no siempre les agradaba que sus mejores hombres se marcharan del convento. El carácter supranacional de las órdenes permitió que siempre hubiese candidatos suficientes. El último grupo de religiosos reunido por Cisneros, y al mismo tiempo el primero del reinado de Carlos V, estaba formado casi enteramente por medicantes franceses: la mayoría eran bretones, y tan sólo algún que otro picardo o flamenco, aunque la empresa se conoce como la expedición picarda.

El desenvolvimiento político de Castilla en los primeros años del siglo XVı puede ofrecer una posible explicación de la ausencia de los flamencos. Después de la muerte de Isabel en 1504, Felipe el Hermoso hizo valer los derechos al trono de su esposa. En septiembre de 1505 salió en efecto de Flandes, rumbo a la península Ibérica. El esplendor de su corte provocó envidia entre los castellanos. Algunas decisiones políticas suyas -entre las cuales destaca el suspenso de toda actividad inquisitorial- no fueron precisamente aceptadas con gratitud por Cisneros y los Grandes del reino. Un año después, en 1506, murió el duque, pero su breve estancia había dejado cierto sentimiento de malestar. Desde aquel momento se desarrollaba en Castilla una imagen negativa de Flandes y de los flamencos que, aunque se cristalizaba sobre todo bajo Carlos V, tuvo su origen en la confrontación entre la cultura política borgoñesa y la meridional. Quizás por estas razones Fernando y Cisneros, el primero que a causa de las pretensiones de Felipe tuvo que retirarse en Aragón, guardaban cierto rencor hacia misioneros de los Países Bajos. El hecho 
de que en la expedición de 1517 participasen de nuevo dos flamencos, fue tal vez una primera muestra de la influencia del nuevo régimen representado por Adriaan Boeyens, corregente en la espera de la llegada de Carlos V.

La lucha entre observantes y conventuales dentro de la orden franciscana, que sólo terminó en 1571, constituía quizás otra razón. Hasta aquel momento puede haber sido importante para los guardianes de las comunidades observantes no dejar que los mejores elementos se marchasen de sus conventos.

\section{LA AMÉRICA DE FLANDES}

Un segundo e inesperado giro en la historia dinástica de Europa traería consigo consecuencias para la participación de Flandes en la evangelización de América. La proclamación de Carlos como rey de Castilla y Aragón despertaba grandes esperanzas, pero al llegar a la península, el nuevo rey no produjo precisamente una impresión favorable. Su típica mandíbula habsburguesa le dio un aspecto un poco idiota; sabía poco o nada de los asuntos españoles de estado, no hablabla castellano y además se rodeaba de consejeros flamencos que, según se creía, sólo pensaban en poder y dinero. Pronto resultó que los castellanos no dejaban de tener razón. Guillermo de Croy, señor de Chièvres y gentilhombre del rey, le dominaba a éste por completo y repartía puestos importantes entre sus familiares y conocidos. A su primo de dieciséis años de edad le nombró arzobispo de Toledo. Adriaan Boeyens, antiguo preceptor de Carlos V, recibió el obispado de Tortosa y por tanto el puesto de Inquisidor General. La avaricia del canciller Jean le Sauvage se hizo legendaria. Los consejeros flamencos se comportaban como en territorio ocupado. Se decía que consideraban a España como su América, como un país de donde podian sacar impunemente las riquezas.

La misma tendencia parecia imponerse en los asuntos de América. Los consejeros flamencos se introdujeron en el Consejo de Castilla. Las riquezas de las colonias pasaban a Flandes. A Laurent de Gorrevod, gobernador de Bresse, fue al primero que se le permitió llevar una carga de esclavos negros a las Antillas para substituir a los trabajadores indios. No tardó en vender la licencia a unos genoveses. Según Las Casas, el misterioso Almirante de Flandes, del cual Marcel Bataillon sospecha que era Adolfo de Borgoña, señor de Veere, recibió en feudo, en 1518, el recién descubierto Yucatán y organizó una expedición de cinco barcos de labradores flamencos. La historia parece muy dudosa. Menos dudoso fue el nombramiento de Pierre Barbier, capellán de le Sauvage y más 
tarde de Carondolet, como obispo de la futura diócesis en las costas de Paria y Cumaná. Al mismo tiempo se nombró al dominico Jan de Witte, confesor de la hermana de Carlos, Eleonora, como obispo de Cuba. Probablemente nunca residió en su diócesis. Con el dinero de su título se construyó una casa en la Garenmarkt en Brujas, llamada la Corte de Cuba. En marzo de 1518, Erasmo escribió desde Lovaina a Barbier, felicitándole por su nombramiento, que "aquí vivimos en el pensamiento que allá se encuentran regiones enteras cuyo suelo es de oro puro, pero donde, contrariamente a India, no hay hormigas para vigilarlo y, por tanto, uno puede recoger la cantidad que quiera".

Sin embargo, fue en esta Corte, según tantos contemporáneos españoles, muy viciosa y corrupta, donde también se trabajaba en la protección de los indios contra sus colonizadores. En marzo de 1516 los regentes Cisneros y Boeyens recibieron por primera vez un memorial de Las Casas en el cual éste describió los actos de crueldad y atrocidad que los españoles cometían frecuentemente contra los indios. Ambos hombres se mostraron indignados del comportamiento de los españoles en América, Cisneros, según Las Casas, porque era un hombre benigno y generoso. Por otra parte, sobre Adriaan, Las Casas decía que era piadoso y sincero, "lo uno por ser de nación flamenca, que según parece son gente más que otra quieta y no cruel, lo otro por su condición particular benigna y mansueta". Los regentes permitieron a Las Casas adoptar las Leyes de Burgos de 1512, quien después volvió a Hispaniola en compañía de tres jerónimos cuya tarea fue la de poner en ejecución las leyes nuevamente formuladas.

Las Casas, considerando que los jerónimos se dejaban influenciar demasiado por los colonizadores, volvió a España a fines de mayo de 1571 con cartas de recomendación del provincial de los dominicanos en Hispaniola y de los franciscanos de Picasdia que intentaban evangelizar pacíficamente las costas de Tierra Firme. En España le esperó un frío recibimiento, en buena parte causado por las quejas sobre su persona que los jerónimos habían dirigido a Cisneros. En septiembre del mismo año, la Corte real se instaló en la Península. Las Casas no tardó en contactar con le Sauvage. Las cartas de los picardos le favorecieron mucho, ya que también eran conocidos del canciller. Barbier le tenía aprecio. Incluso Chièvres se reveló como protector suyo, to que explica la opinión tan diferente de la de sus contemporáneos que Las Casas tenía del consejero. Se le permitió redactar otro memorial en el cual pidió más colonizadores para Hispaniola, donde la población autóctona había sido casi exterminada y, además, el traslado de esclavos negros para substituir a los trabajadores indios. Esta decisión dio ocasión a la ya mencionada licencia de Gorrevord. El plan de una colonización agraria del Nuevo Mundo tam- 
bién era suyo y puede haber inspirado al Almirante de Flandes poblar Yucatán con labradores flamencos, en el caso de ser verídica la historia. Sin embargo, Las Casas de repente dejó de lado estos planes para dedicarse a un proyecto de colonización y evangelización pacífica en las costas de Tierra Firme en una zona todavía no explotada por los españoles. La Corte continuaba creyendo en él.

\section{ENCUENTRO DE DOS MUNDOS}

Parece, por tanto, que en la Corte de Carlos V, ya emperador, se encontraban dos mundos diferentes, que, cada uno a su manera con influencias mutuas, desempeñarian un papel importante en el desarrollo del proyecto colonial. El primer mundo, personificado por Las Casas, representaba la conciencia incipiente de un grupo de religiosos que, al contemplar la situación lastimosa de los indios, interpretaban convencidos que esto no podía haber sido el propósito de Dios cuando dispuso que los españoles descubriesen el Nuevo Mundo. El otro era el mundo del humanismo, encabezado por el mismo emperador, que las crónicas del descubrimiento y de la conquista de América siempre alababan por su actitud honesta y justa en el gobierno de las colonias. El emperador mismo había recibido una educación al estilo renacentista. Su preceptor Boeyens, el futuro Papa Adriano VI, experimentaba fuertemente la influencia de la Devoción Moderna. En Roma sería el hazmerreír de los italianos por su parsimonia y su falta de fastuosidad. Carlos admiraba mucho a Erasmo, que dedicó la primera edición de su Instituto principis christiani al emperador y la segunda incluso a Chiévres. Tomás Moro, íntimo amigo de Erasmo, publicó en 1516 en Lovaina su Utopia, cuya lectura podría haber hecho susceptible a la Corte de los proyectos lascasianos de colonización pacífica de Tierra Firme.

Más importante era probablemente el influjo que sufrían el emperador y su contorno de fray Francisco de los Ángeles, alias Quiñones. Quiñones entró en contacto con Carlos $V$ por Cisneros y desempeñó un papel fundamental de negociador en la revuelta de los comuneros. Siendo paje de Cisneros había visto cómo el cardenal reformó la orden de los franciscanos en España. Había presenciado las protestas de los mendicantes toledanos en las calles de su ciudad. Había visto cómo numerosos frailes de otros conventos colgaron sus hábitos o huyeron al Islam porque Cisneros les impuso la regla estricta de Francisco de Asís. El mismo Quiñones se dejaba influenciar mucho por la reforma de fray Juan de Guadalupe en Extremadura. Los descubrimientos de Colón en 1492 habian inspirado a este último pensamientos escatológicos. Colón pensaba que el Orinoco 
era uno de los cuatro ríos del Paraíso y muchos otros después situaban el Jardín de Edén en América. Si Dios revelase a los cristianos un mundo desconocido y les llevase tan cerca al Paraíso, el día del Juicio Final debería situarse en un futuro no muy lejano. En este ambiente Guadalupe emprendió una reforma del movimiento de los observantes. Empezó en Granada, con permiso papal, un experimento para poner en práctica el ideal de San Francisco. Halló una resistencia vigorosa, también de la parte de los observantes. Sólo en 1500 tuvo éxito, cuando cinco conventos en Extremadura se unieron a su reforma. En 1517 el movimiento culminaría en la provincia independiente de San Gabriel.

Una consecuencia importante de la reforma de Guadalupe era el resurgimiento del milenarismo de Joaquín de Fiore en la España de los primeros años del siglo xVi y sobre todo en Extremadura, tierra de conquistadores. Las perspectivas del joaquinismo ofrecian una respuesta satisfactoria al descubrimiento de un nuevo continente con nuevas civilizaciones, que había alterado de una manera profunda la imagen del mundo medieval. El fin del mundo se acercaba. Se trataba de desempeñar un papel decisivo y activo en el cumplimiento de las profecías escatológicas. De la conversión de los indios dependía la consumación de las promesas del Apocalipsis. Al volver a la pobreza evangélica, Guadalupe había preparado su movimiento para esta tarea. La primera expedición de misioneros españoles a Méjico, organizada por Quiñones, estaba formada enteramente por partidarios fervientes del movimiento de reforma extremeño.

Por consejo de Quiñones el emperador nombró en 1521 a Jehan Glapion como su confesor. Nacido alrededor de 1460 en Le Mans, había entrado en el convento de los franciscanos conventuales en dicha ciudad. Probablemente desde los años ochenta permanecia en los Países Bajos, pero sólo en 1510 se le nombró como guardián del convento de los observantes de Brujas, donde protegía a su comunidad contra los ataques de los conventuales. Siendo comisario de los observantes, tuvo mucha influencia en la decisión papal de 1517 para confiar el gobierno de la orden franciscana ultramontana a los observantes. Como confesor del emperador apoyaba a éste en su lucha contra el luteranismo incipiente. También Glapion, como su amigo Erasmo y Quiñones, esperaba durante mucho tiempo que Lutero tomase una posición más moderada contra Roma para hacerse un aliado poderoso en la reforma de la Iglesia. Pronto resultó ser nada más que una ilusión.

\section{¿POR ORDEN IMPERIAL O POR PROPIA VOLUNTAD?}

En este mundo de profecías apocalípticas e ideales milenaristas, la conquista de Méjico por Cortés cayó como una bomba. Los españoles 
encontraron una serie de civilizaciones muy superiores a las de las Antillas, donde los indios andaban desnudos y donde algunas tribus practicaban el canibalismo. La tradición cuenta que el entusiasmo entre los observantes era tal que Glapion y Quiñones viajaron a Roma para conseguir del Papa, el 25 de abril de 1521, la bula Alias felicis recordationis, que otorgaba a la orden franciscana poderes episcopales en regiones donde no residía obispo. Por tanto, les estaba permitido administrar los sacramentos, consagrar altares, iglesias y cementerios, otorgar indulgencias, excomulgar y reconciliar a los excomulgados con la Iglesia, en breve, ejercer los poderes del clero secular para emprender la evangelización de la tierra recién conquistada. El Papa les encargó a Quiñones y a Glapion el reclutamiento de misioneros. Seguidamente, Juan de Tecto, Juan Aora y Pedro de Gante se presentaron en Glapion. A fines de mayo de 1522 el grupo viajó con el emperador a España. Mientras tanto, Adriano VI promulgó la bula Omnimoda, que confirmaba una vez más las competencias específicas de las órdenes medicantes y, sobre todo, de los franciscanos. Glapion murió en 1522 en Valladolid, mientras que Quiñones fue elegido vicario general en el Capítulo General de su orden que tuvo lugar en 1523 en Burgos, viéndose impedido de realizar la travesía a las colonias. Por tanto, los tres flamencos partieron solos. Llegaron a Méjico, el 30 de agosto de 1523 y empezaron con la conversión de los indios.

Esta historia aparece ya en las primeras crónicas sobre la conquista de Méjico, como la de Jerónimo de Mendieta. La mayoría de los historiadores la han copiado de allí. Sin embargo, varios datos contradicen tal desarrollo de los acontecimientos.

En el momento de promulgar las bulas, el Papa León $X$ era poco probable que pudiera haberse enterado de la conquista del imperio de los Aztecas. La primera carta de Cortés, recibida por el emperador en mayo de 1520, se escribió en julio de 1519, cuando los españoles estaban todavía en Veracruz y no habían empezado su viaje al interior del país. La segunda carta, que describió la caida del imperio azteca y la toma de Tenochtitlán, llegó al emperador no antes del otoño de 1521. Por tanto, la tesis que defiende que Carlos V mandase a su confesor Glapion a Roma para rogar al Papa que concediese las facilidades mencionadas, tal como lo cuenta Mendieta en su Historia eclesiástica indiana, no corresponde a los acontecimientos. Además, la bula no menciona en ningún momento la conquista de Méjico, pero habla de «las islas de las Indias y otras provincias sujetas a nuestro Carísimo hijo en Cristo, Carlos". Tampoco se mencionan los nombres de Glapion o Quiñones. De todas formas, es imposible que Glapion estuviese en Roma en abril de 1521, ya que en aquel momento participaba como delegado imperial en la Dieta de Worms. Tampoco cabe pensar que el emperador mandase a las colonias a uno 
de sus mejores peones en la lucha contra el luteranismo en un momento en que este problema parecía lejos de estar resuelto. Glapion podría prestarle aún muchos servicios contra Lutero. El único papel posible de Glapion en el asunto de las bulas es el de mediador con los delegados papales en Worms.

Por tanto, parece que León X no promulgó la bula Alias felicis recordationis para dar comienzo a la evangelización de Méjico. Probablemente la otorgó en el marco del proyecto de Las Casas de evangelización pacífica de las costas de Tierra Firme a la altura de Cumaná. En 1520 el emperador había presentado a Pierre Barbier como obispo de la costa y había encargado a su embajador en Roma conseguir del Papa las bulas necesarias para la ejecución del proyecto. Para agradar al emperador, es posible que el Papa otorgase Alias felicis como apoyo suplementario a la empresa que aparentemente era de gran importancia para el emperador y sus consejeros. Su precaria posición política y militar en 1520 puede haberle inspirado. Hasta entonces había hecho el doble juego en la lucha entre Carlos $\mathrm{V}$ y Francisco $\mathrm{I}$, y varias veces había tomado partido por Francisco, pero cuando en aquel año Carlos se mostró vencedor, los intentos de aproximación de su parte se multiplicaron cada vez más. Barbier, por lo demás, desistiría en octubre de 1521 de la travesía a Tierra Firme después de recibir las noticias del fracaso de intentos anteriores de evangelización pacífica por resistencia de los mismos indios.

Con la bula Omnimoda del Papa Adriano VI, promulgada el 10 de mayo de 1522, o sea dos meses antes de su salida para Roma, las cosas eran diferentes. Hacía medio año que el emperador había recibido las noticias de la toma de Tenochtilán y no es probable que no hubiera informado a su antiguo preceptor quien hasta enero de 1522 era regente de Castilla y Aragón. En la bula también se habla de udos o tres o más (frailes) que en las dichas tierras les precedan». Este fragmento se refiere más bien a la exploración de un territorio desconocido que a las bien conocidas islas y las costas de Tierra Firme, aunque no se menciona la conquista de Cortés en ningún momento.

A pesar de esto, es aún muy discutible si la bula se otorgó especialmente para los tres flamencos de Gante, o sea, si es cierto que antes del 10 de mayo de 1522 los tres se presentaron ante el emperador 0 ante Glapion, por su propia voluntad y entusiasmados por irse a Méjico, como lo cuentan los cronistas. Investigaciones posteriores deberán aclarar este asunto. Sin embargo, varios elementos ya contradicen tal versión de los hechos.

Mendieta escribe de Tecto y sus compañeros: "y su ventura fue, juntamente con su buena diligencia, el favor de los grandes de Flandes, como 
a la sazón mandaban en España; pero no fue con autoridad del Papa, aunque con licencia del Emperador, y así no hicieron cosa de propósito, hasta que vinieron los doce que la trajeron". Según Mendieta, los flamencos no tenían permiso papal y por tanto no podían gozar de los privilegios que la bula Omnimoda otorgaba a los franciscanos. En la bula tampoco se habla del estatuto de Gante, aunque siendo fraile lego no podía pretender las facilidades episcopales concedidas a los mendicantes. Entonces, ¿por qué mandar a un fraile lego a evangelizar Nueva España sin darle antes las competencias necesarias?

El mismo Gante escribió en su carta a Felipe II que se enteró de la conquista de Méjico después de llegar a España. Ahora bien. La flota imperial salió de Calais a inicios de mayo de 1522 y llegó al puerto de Santander el 27 de julio, después de una estancia en Inglaterra donde Carlos negoció con Enrique VIII sobre una posible alianza, y más de un mes después de la promulgación de Omnimodi. Además, Gante añade que el emperador los mandó a América y no habla en ninguna parte de una iniciativa suya. Durante el viaje a España los flamencos tampoco viajaron en el mismo barco que Glapion, el supuesto líder de la expedición.

Por último, una serie de cédulas reales de 1522 vierte inesperada luz sobre el asunto. El 31 de agosto de 1522 el emperador ordenó a sus funcionarios en Sevilla

\begin{abstract}
"que fray Juan de Tecto y fray Juan de Arévalo, frailes de la Orden de San Francisco, van por comisión de sus prelados y con voluntad y consentimiento nuestro a las Indias, islas e tierra firme del mar Océano, a visitar los frailes de su Orden (...) vos mando que deis a los dichos fray Juan de Tecto y fray Juan de Arévalo y sendos compañeros (...) pasaje franco en mantenimientos (...) desde esa ciudad hasta la isla donde primeramente quieren ir a entender en lo susodicho, porque de ahí adelante han de ser proveídos por los nuestros oficiales de cada isla". Una orden similar se la mandó a Diego Colón, gobernador de Hispaniola: «Fray Juan de Tecto y fray Juan de Arévalo (...) van por comisión de sus prelados y voluntad y consentimiento nuestro a esas partes a visitar los frailes de su Orden (...) y ver lo que de ellos son útiles e idóneos para estar e residir en esas partes y hacer fruto en la instrucción y doctrina de los moradores de ellas y las otras cosas de su oficio queden, y los que no fueren tales los hagan venir a sus monesterios, como veréis por su poder e comisión".
\end{abstract}

Los gobernadores y funcionarios reales de Jamaica, Cuba, Puerto Rico y Tierra Firme recibieron mandatos iguales. El 20 de marzo de 1523 se les entregó a Tecto y su compañero víveres para el viaje de Sevilla a Hispaniola. Del otro grupo, no hay noticias, aunque es lógico que si en la realidad formasen dos grupos, como lo sugieren los documentos («fray 
Juan de Tecto y fray Juan de Arévalo y 'sendos' compañeros), también se les pagase separadamente. El 10 de mayo los cuatro hombres embarcaron. A mediados de agosto el tesorero de Santo Domingo hizo relación de la entrega de una suma de dinero a Tecto y a sus compañeros, para la compra de víveres. Viajaron de Santo Domingo a Cuba y de allí a Nueva España. El hecho de que Gante ni siquiera se llevase una biblia en el viaje deja entrever una vez más que la misión de los flamencos en efecto se limitó a un viaje de inspección y en modo alguno tuvo como único fin el inicio de la evangelización de Méjico.

Tal como están las cosas parece que poco antes y después de llegar las noticias de la conquista del imperio azteca, el emperador mandó organizar dos expediciones que en una primera fase acaso no tenían nada que ver entre sí. Una primera expedición tenía como objetivo el control de todos los misioneros franciscanos en el Nuevo Mundo. Se la confió a Tecto, Arévalo y dos compañeros. El papel de los franciscanos en la rebelión de los comuneros y los disturbios que provocaron en varias ciudades españolas entre 1517 y 1521 pueden haber sido el motivo principal. Esto explicaría también por qué el emperador eligió mendicantes «flamencos» para la misión. Una segunda expedición, organizada por Glapion y Quiñones y para la cual se obtuvo de Adriano VI la bula necesaria, debía reunir un grupo de misioneros con el fin de mandarlos a los territorios recién conquistados para iniciar la cristianización de Méjico.

Después de llegar a la península lbérica, la misión de Tecto y Arévalo se concretó rápidamente. Las cédulas reales de agosto de 1522 parecen haber descartado los últimos obstáculos para su salida. La expedición de los misioneros, al contrario, se vio retardada por la muerte de Glapion en septiembre de 1522. Quiñones estaba demasiado ocupado con los intentos de reconciliación entre el emperador y los comuneros. Después estimó que era mejor esperar hasta el Capítulo General de la orden franciscana en Burgos, la única autoridad competente en la elección de mendicantes para América. Su elección impidió la travesía a Nueva España. La expedición se retrasó otra vez. Sólo en enero de 1524 embarcarían los doce franciscanos españoles bajo el mando de Martín de Valencia.

Al contrario, Tecto estuvo dispuesto ya a inicios de marzo 1523 a partir, aunque al final el viaje se retrasó hasta mayo. Personalmente, pienso que el hecho de que no esperasen el Capítulo General de su orden, que empezó unos días después, prueba una vez más que los flamencos no salian como misioneros. Sin embargo, y visto el retraso de la expedición de Quiñones, es posible que Carlos $V$ les mandase viajar hasta Nueva España. A juzgar por las cédulas reales de agosto 1522 esto no formaba parte de su misión original y en el marco de la inspección pretendida 
tampoco tenía mucho sentido: en toda Nueva España se hallaban apenas dos franciscanos que, además, no se dedicaban a evangelizar sino solamente asistían a los españoles. Quizás el emperador considerase oportuno tener algunos hombres de confianza próximos a Cortés, ahora que éste se había desprendido sin grandes problemas de la autoridad de Velázquez. Esto explicaría por qué Tecto y Aora acompañaron a Cortés en la expedición que hizo a Honduras para recuperar las tierras que Cristóbal de Olid había conquistado. Quizás el emperador sólo se acordase del consejo de su preceptor y amigo Adriano VI de mandar primero a unos exploradores antes de montar una empresa más extensa.

\section{EN LAS HUELLAS DE CORTÉS}

Sea lo que fuese el verdadero motivo de los flamencos, el hecho es que después de un viaje de tres meses y visitas a Hispaniola y Cuba, los tres - no se sabe lo que pasó con Arévalo- llegaron a Veracruz el 30 de agosto de 1523. Tal vez Cortés se sorprendió de que el emperador le mandase flamencos que apenas hablaban castellano. Sin embargo, les recibió cordialmente y les alojó con el rey Ixtlixochitl, aliado de los españoles, en el palacio de Netzahualpilli en Texcoco. El rey sí les rogó no mostrarse demasiado en público para no escandalizar a la población indigena y sus caciques.

Aparte de algunos datos fragmentados, se sabe muy poco de los tres flamencos. Aora parece el más misterioso. Los primeros cronistas sólo cuentan de él que ya tenía sus años al llegar a Veracruz y le califican como hombre sabio. Incluso Pedro de Gante olvidó pronto su nombre y en sus cartas a Carlos $V$ y Felipe II sólo le menciona como "el otro sacerdote». Juan del Tecto estudió en la Sorbona y luego enseñó durante catorce años teología en la misma universidad. En 1516 sucedió a Jehan Glapion como guardián del convento de Brujas. Pocos años después ejerció de guardián en el de Gante. Antes de salir para el Nuevo Mundo era como Glapion, confesor del emperador. Montolinía, uno de los Doce, diría de él: "Creo no haber pasado a estas partes letrado más fundado que él». Según la tradición, Pedro de Gante era pariente del mismo emperador y estudió en la universidad de Lovaina. La última aserción forma parte del proceso de mitificación de su figura. Muchas fuentes le califican como un hombre práctico pero sin estudios. También sus cartas revelan una cultura más bien limitada. Igual se duda de su parentesco con el emperador. Gante escribe una vez que era utan allegado a Vuesta Magestad y (...) de su tierra". Quizás la palabra "allegado" se refiere más bien a un sentimiento de afección entre compatriotas. Por lo demás Gante tenía que 
presentarse ampliamente en cada carta que escribía al emperador, refiriéndose al viaje de Flandes a España en compañía del monarca, Glapion y Quiñones. A Felipe II ni siquera se presentó como pariente de su padre, lo que hubiera sido una introducción mucho mejor para conseguir el apoyo del rey. Algunos personifican a Gante con el misterioso "monsior de la Mura» que participó en las negociaciones entre la Corte y Las Casas. Pero Las Casas menciona en sus escritos tanto a Mura como a Gante sin relacionar el uno con el otro. Existe la posibilidad de que Las Casas no se imaginara nunca que ambos personajes eran uno mismo. Eso significaría que Gante entró ya en 1516 al servicio de Carlos V. En efecto, Gante cuenta a Felipe II que "desde muy mozo me he ocupado en cosas tocantes al servicio de la Corona Real, antes de mi conversión, y después acá muy mucho mejor». Entonces la cuestión es por qué no mencionó este servicio como referencia al emperador, en vez de referirse a la ciudad donde ambos crecieron. Por otra parte es cierto que ya en 1522 había ingresado en el convento de los franciscanos en Gante. Por tanto, es plausible que el vínculo entre Carlos $V$ y Pedro de Gante no fuese de parentesco. Más bien eran conocidos por su amigo en común, Juan de Tecto.

Estos tres mendicantes flamencos encontraron en Texcoco una sociedad desequilibrada en la cual lo religioso predominaba y las formas de comportarse de los súbditos se basaban en su miedo por los numerosos dioses. Gante escribiría en 1529 a sus padres y sus hermanos de hábito en Flandes:

"Los nacidos en esta tierra son de bonísima complexión y natural, aptos para todo, y más para recibir nuestra santa fe. Pero tienen de malo el ser de condición servil, porque nada hacen sino forzados, y cosa ninguna por amor y buen trato; aunque en esto no parecen seguir su propia naturaleza, sino la costumbre, porque nunca aprendieron a obrar por amor a la virtud, sino por temor y miedo. Todos sus sacrificios, que eran de matar a sus propios hijos o mutilarlos, los hacían por gran temor, no por amor a sus dioses".

Habla de por sí el hecho de que los flamencos tuvieron que superar primero el recelo de los indios. Sin embargo, Ixtlixochitl les permitió pronto enseñar la doctrina católica a varios hijos de familias indígenas nobles. El mismo Ixtlixochitl les pidió enseñanza para él y su familia, probablemente considerando que si en el futuro quisiera desempeñar un papel de cierta importancia en el nuevo orden social, la conversión a la religión de los españoles sería una condición absoluta. De tal manera esbozaron las grandes líneas de su método de conversión: enseñanza a la población sirviéndose de los niños y con el apoyo de los jefes indios. Trataron de 
aprender el Náhuatl para un contacto más fácil con la población. No hacían el menor esfuerzo por enseñar el español a los indios, a pesar de que desde los Reyes Católicos, la Corona española seguía una política de españolización, recordando la célebre frase de Nebrija que la lengua debiera ser compañera del Imperio. Los franciscanos contrariaban lo más posible esta política. Aún en 1553 Gante recibió la orden de dejar la enseñanza en Náhuatl y de servirse del español para comunicarse con los indios.

El estudio de las lenguas avanzó bien. Pronto Tecto se vio capaz de traducir los fundamentos de la doctrina católica al Náhuatl. Pero todavía no llegaban a erradicar las creencias que los indígenas tenían de sus dioses. Por el momento no les estaba permitido bautizar, ya que habían venido a Nueva España sin permiso papal. En mayo de 1524 los Doce llegaron desde España. Se celebró una primera misa. Poco tiempo después se habría producido en el convento de Texcoco una escena muy famosa de la historia misionera. Cuando Martín de Valencia vio que los indios todavía adoraban a sus ídolos y que no se había derribado ningún templo, les preguntó a los flamencos qué demonios habian hecho hasta entonces. Tecto le contestó que se habían entretenido aprendiendo una teología que San Agustín había ignorado por completo, refiriéndose al estudio de idiomas. Es muy improbable que esta actitud surgiese de un profundo respeto para la cultura india. Simplemente los flamencos se daban cuenta de que, si querían penetrar en el alma del indio, deberían primero aprender a comunicarse con ellos.

De todas formas, los tres flamencos se sometieron al mando de Valencia, obedeciendo las directivas que Quiñones le había dado a éste. Se decidió dividirse en grupos de dos o tres hombres y de dispersarse en la región de Tlaxcala para formar núcleos desde donde se desarrollaría la evangelización. Aora y Gante volvieron a Texcoco para seguir con su trabajo. Entre los primeros indios bautizados se encontraba Ixtlixochitl y su familia. Se organizaron bautismos en masa que pretendían acoger en el seno de la Iglesia a cuantos indios fuera posible. Tecto defendió esta manera de trabajar en su Apología del bautismo Administrado a los gentiles Mexicanos con solo el agua y la forma sacramental. Los bautismos en masa fueron resultado de la convicción de los franciscanos de que el fin del mundo se estaba acercando rápidamente. Al bautizar a todos los indios, las profecias del Apocalipsis se podrían cumplir. Los agustinos, pero sobre todo los dominicos, acusarían luego a los franciscanos de bautizar demasiado rápido a los indios, sin las ceremonias necesarias y con la cantidad de bautizados como única referencia. Mientras, ellos bautizaban menos en masa y dedicaban más tiempo a la enseñanza previa. La controversia ocuparía buena parte del siglo XVI. 
Aora y Tecto no permanecieron mucho tiempo en compañía de Gante. Mendieta refiere que Aora murió pocos días después de llegar con Gante a Texcoco y que su cuerpo se enterró en primera instancia en la casa de Ixtlixochitl. Tecto habría muerto de hambre en Honduras. Mendieta se equivoca. "Ambos" flamencos acompañaron a Cortés en su expedición a Honduras. En el viaje Cortés hizo ahorcar por traición al último rey azteca, Cuauthémoc. Se dice que Tecto defendió ardientemente al rey y que por eso Cortés le condenó a muerte. Esta hipótesis se basa en un dibujo del Códice 3738 de la Biblioteca Vaticana. En este códice se ve a Cuauthémoc y a otro presunto traidor colgados de un árbol en compañía de un fraile franciscano. Sin embargo, Bernal Díaz del Castillo, testigo presencial, cuenta en su Historia de la Conquista de Nueva España que los dos se ahogaron en el Golfo de Méjico. En su quinta carta a Carlos V, del 3 de septiembre de 1526, Cortés confirma el relato de Bernal Díaz.

\section{PEDRO DE GANTE, PADRE DE LOS INDIOS}

Mientras tanto, Pedro de Gante siguió con la conversión de los indios en Tlaxcala y a partir de 1526 en Tenochtitlán en colaboración con los otros franciscanos, entre los cuales estaban Motolinía y Zumárraga. Fue allí, en Tenochtitlán, donde construyó la primera iglesia de Nueva España, la Capilla de San José de los Naturales, al lado del convento franciscano. La base de la evangelización seguía siendo la enseñanza a los niños de los indios nobles. Dado que el número de franciscanos era limitado, les fue imposible encargarse personalmente de la enseñanza de todos los indios. Por tanto, hicieron participar a los niños en su actividad misionera, una táctica que daba resultados muy satisfactorios y que aseguraba el futuro de la religión católica en Méjico. Preparándolos de tal manera, los niños incluso podían volver a sus pueblos durante el fin de semana para predicar y divulgar la fe. Gante tenía bajo su tutela continuamente unos quinientos alumnos, de los cuales solía preparar cincuenta para la predicación. Los franciscanos les dividían regularmente en grupos pequeños e iban de un pueblo a otro para destruir templos e imágenes. Construían oratorios cristianos, de capillas humildes a iglesias imponentes. Al mismo tiempo se enseñaba a los indios y se les preparaba para el bautismo. Se solía bautizar a miles de personas a la vez. Siendo fraile lego, Gante asistía y ayudaba. Perseguía a los falsos convertidos y les hacía castigar, como en 1536, cuando descubrió a un curandero que secretamente había seguido con sus prácticas.

La enseñanza de Gante consistía en primera instancia en la doctrina católica. En la época en la cual los indígenas aún no sabían leer o escribir 
el alfabeto latino, se servía de un Catecismo de la doctrina cristiana en jeroglíficos para la enseñanza de los Indios Americanos, un testeriano, de hecho una especie de historieta que había diseñado él mismo sin basarse en las pictografías de los aztecas. Después compuso, probablemente con la ayuda de las notas de Tecto, una Doctrina Cristiana en lengua Mexicana que se imprimió en Amberes en 1528. Es la primera obra impresa enteramente en Náhuatl.

Aparte de la doctrina católica, Gante les enseñaba a escribir y leer, siempre en Náhuatl. Para tal fin transformaba las pictografías aztecas en letras del alfabeto latino. Negaba enseñar el español, que él mismo había aprendido a fondo en Méjico. No fue una excepción entre los franciscanos. Los mendicantes de Nueva España negaban dar su enseñanza en español y preferían mantener separados a los indios de los españoles por miedo de que estos últimos los estorbasen por su mala influencia en el trabajo de evangelización. No hay evidencia en sus cartas si la motivación de Gante estaba influenciada por las ideas milenaristas que tanto éxito tenían entre los miembros de su orden. Más bien parecía ser un hombre práctico que no prestaba mucha atención a las profecías. El hecho de que los indios sólo entendian conceptos de la religión católica después de haberlos traducido al Náhuatl, habría jugado un papel más decisivo.

Gante no sólo prestaba atención a la educación teórica. También se dedicaba a la enseñanza de varios oficios. Trataba de crear una sociedad capaz de proveerse de las necesidades materiales, religiosas y culturales para que con el tiempo la ayuda que recibía desde España se hiciese superflua. El elemento material y cultural siempre se sometía al religioso. Enseñaba a los indios cómo pintar, entallar, tejer, hacer herramientas, etcétera. Antes de la llegada de los Doce utilizó objetos rituales del tesoro de Netzahualcoyotl como adornos de su capilla primitiva en Texcoco, pero pronto los talleres de sus alumnos producian las imágenes y pinturas necesarias. Al principio el proceso se desarrolló con dificultades porque los indios no estaban familiarizados con la representación de la figura humana al natural, pero la técnica mejoró visiblemente al importar pinturas y grabados de Flandes, Italia y España en las cuales se podían basar. El número de pintores aumentó de tal forma que el virrey Luis de Velasco les puso en 1552 bajo la supervisión de Gante porque temía que sin ningún control podrían originarse obras poco ortodoxas.

Bajo la dirección de Gante se producían campanas, estardantes y ropa litúrgica. El flamenco contribuyó en no escasa medida al desarrollo de una arquitectura colonial. El plano de la Capilla de San José, con su balcón y su patio espacioso para misas al aire libre para gran número de gente (la llamada capilla abierta), se repetirá en todo el Nuevo Mundo. 
Gante mismo dijo haber construido con la ayuda de los indios más de cien iglesias y capillas. Como cuenta Mendieta, más de un artesano español, que pretendía ganar en Nueva España mucho dinero con su trabajo exclusivo, se decepcionó al ver que los niños le espiaban para aprender las técnicas de su oficio hasta ser capaces de imitarle. Gante notó pronto que en el culto indígena la música desempeñaba un papel importante. Hizo fabricar instrumentos para dar lustre a los servicios religiosos. El hecho de que se encargase a los franciscanos con la dirección del Colegio Indígena de Tlatelolco, no sólo se debía a la intervención del arzobispo Zumárraga y la Audiencia, sino también a la buena fama de la cual en aquel momento gozaban Gante y sus compañeros. Después del descubrimiento de numerosos focos de idolatría, se fundó dicho colegio para dar una mayor profundidad a la evangelización superficial que tenían los indios.

Al lado del convento de los franciscanos, Gante erigió un hospital donde algunos días se curaban hasta cuatrocientos enfermos y heridos. Él mismo visitaba regularmente los pueblos de su distrito para predicar y atender a los enfermos. Gante se daba cuenta de que no se podía esperar de los indios que prestasen atención a los asuntos de la religión si tenian que preocuparse cada día por su bienestar material. Entendía que la presión sobre los indios, con tributos e impuestos, impedía seriamente la evangelización de Méjico. En una carta de 1552 enviada al emperador, aclaró su visión personal de la situación. Cada vez más se revelaba como defensor de los indios contra los abusos de los conquistadores españoles. No se calló e hizo notar al monarca que tenía una responsabilidad como monarca cristiano. Condenó los tributos excesivos, el trabajo duro en las minas de plata y en la construcción, los servicios personales que se incluían en la encomienda, el sueldo miserable y la ocupación de sus tierras. Con la fundación de la Hermandad del Santísimo Sacramento, intentó devolver a la sociedad india su columna vertebral que los españoles habian quitado. La Hermandad organizaba todas las procesiones de la Semana Santa. Carlos $V$ y el Papa le ofrecieron varias veces el sacramento del orden y hasta el puesto de obispo para que defendiese mejor a los indios. Gante consideraba que tal honor no le ayudaría mucho en su tarea y nunca aceptó. No por eso su influencia bajó. El sucesor de Zumárraga, Alonso de Montúfar, solía decir: "Yo no soy arzobispo de México, sino fray Pedro de Gante, lego de San Francisco».

Los indios apreciaban a los franciscanos por sus esfuerzos en la lucha para su bienestar. En el momento de la repartición de las regiones misioneras, al contrario, fueron las víctimas de la envidia de otras órdenes en Nueva España. Se decía que antes se reservaban pueblos enteros para sí mismos que dejarlos a otras órdenes, con la consecuencia de que se 
decía misa y se predicaba sólo una vez por año. Había casos en que ciertos pueblos negaron aceptar misioneros de otras órdenes que no fuese la franciscana. En 1554 el dominicano Andrés de Moguer acusó a Gante de haber levantado un pueblo entero contra los dominicos que el arzobispo había enviado. Las relaciones con el clero secular tampoco fueron óptimas. Como la mayoría de los mendicantes, Gante opinaba que el clero secular sólo pretendía prestigio y dinero. Los indios no serían capaces de pagar los diezmos y tributos para su mantenimiento. Los mendicantes, al contrario, no les costaban nada, ya que habían hecho voto de pobreza. Por razones aún desconocidas, Montufar le impuso exilio al flamenco. Pero poco después cuando lo llamó otra vez a Tenochtitlán, los indios lo recibieron afectuosamente. En 1569 tuvo otro conflicto con el clero secular, cuando este último estorbó una procesión que había organizado el día de la Asunción. El incidente caracteriza este período en el cual el clero secular fue quitando poco a poco el poder a los mendicantes.

A pesar de su adaptación rápida y profunda a la sociedad mejicana, Gante nunca se olvidaba de su patria. Varias veces esperaba regresar. En 1558, cuando pensó haber llegado a la etapa final de su vida, rogó al emperador le mandase algunos franciscanos flamencos para que después de su muerte los indios no pensasen que los había abandonado.

Su muerte en 1572, a la edad de casi noventa años, significó una pérdida enorme para los indios y para sus compañeros. Una muchedumbre de gente se presentó a su entierro y muchos llevaron luto. Se dijeron numerosas misas de réquiem y el primer aniversario de su muerte se celebró solemnemente. Varios terratenientes indios y caciques, pero también gente común, se bautizó con su nombre y en algunos casos añadieron incluso el apellido, to que prueba una vez más su impacto sobre la población indígena. Como Las Casas y Motolinía, Gante fue uno de los grandes defensores de los indios de la historia mejicana. Sus alumnos formarían el vínculo entre españoles y autóctonos. En su opinión, como en la de los otros mendicantes, los indios eran hombres, tan hijos de Dios como los europeos. En aquel entonces, esta visión no era muy aceptada. Lo prueba la decisión que tomó Pablo III en 1537, proclamando, después de madura reflexión, que desde aquel momento la Santa Sede consideraba a los indios como hombres. Esta decisión se tomó catorce años después de lo practicado por los franciscanos en América.

\section{MISIONEROS FLAMENCOS EN AMÉRICA CENTRAL}

Al lado de Gante, Aora y Tecto aparecian en el siglo xVI esporádicamente uno que otro flamenco. Es el caso de Simon de Bruselas, fraile 
lego, y Libert Van de Velde que trabajaron en 1535 en Nueva España. Bruselas, que profesó en Brujas, había viajado en 1534 en compañía de Jodoco de Ricke de Santo Domingo a León, en Nicaragua, para llegar el mismo año a la provincia de Quito. Una vez llegado en Tumbes, el punto final de su viaje por mar desde León, y contemplando «la pobreza del país y sus enfermedades, decidió volver a Nicaragua para viajar hasta la buena tierra de Nueva España». Se fue a Nueva Galicia, donde fundó el convento de Amacueca. Allí murió después de haber trabajado más de cincuenta años en aquella región.

Juan de Gante, más conocido como Gandavo, y Francisco de Aragón, ambos franciscanos, fueron enviados en 1533 por el gobernador de Santa María a la ciudad de Granada, a las orillas del lago de Nicaragua, donde volvieron a instalarse en la misión anteriormente abandonada por los franciscanos. Llegaron después de la primavera de 1535, ya que Jodoco de Ricke, que visitó la ciudad de julio de 1534 a mayo de 1535 , notó que «en el país no había frailes». Un año después el dominico Blas del Castillo visitó a Gandavo en Granada. El objetivo era visitar el volcán Masaya, que también había dejado una profunda impresión en Ricke. Los indios adoraban el Masaya como un dios y sus sacerdotes participaban en sacrificios humanos que se producian dejando caer en la boca del volcán a las víctimas. Sólo una expedición al fondo del cráter podría terminar con semejantes prácticas a las víctimas de idolatría. El 12 de junio de 1537 los dos frailes, en compañía de un franciscano francés y de tres españoles, alcanzaron la cumbre. Sin embargo era imposible saber desde alli en qué consistía la materia existente en el fondo del cráter. Juan de Gante, que ya había subido una vez al Masaya y que estaba ansioso por conocer su secreto, aseguró que la materia ardiente sólo podía ser oro, plata u otro metal precioso. Otros pensaban ver hierro, agua o azufre. Se decía incluso que el volcán era una ventosa del infierno. De todas formas, se pusieron de acuerdo en que el gobierno debería haberlo investigado antes para estimular la conversión de los indios al catolicismo. Volvieron a Granada, donde montaron una expedición para bajar al cráter. Después de varios intentos fracasados, una última expedición en 1538 probó que la materia no era más que lava ardiente. Sin embargo, lo que parece ser un acto de sacrificio en nombre de la fe, era según el cronista Gonzalo Fernández de Oviedo en su Historia de Nicaragua nada más que el resultado de la avaricia de Blas del Castillo y sus compañeros. Oviedo opinaba que lo más importante para ellos era la posible existencia de plata en el cráter y no la salvación de las almas indígenas. Quizás tenía razón. Una cédula real del 12 de junio de 1540 mandó la detención de un tal fray Francisco Aragonés, «fraile de mala vida", y de fray Juan Gandavo, «flamenco de igual vida", que a pesar de las advertencias del guardián de Toledo habían 
hecho la travesía a Indias. Sin embargo, aun en 1541, Gandavo escribió una carta al Consejo de Indias para defender el trabajo suyo y de sus compañeros de orden, atacando al mismo tiempo la actitud de los conquistadores españoles.

En los años sesenta, fray Andrés de Bruselas trabajaba en el convento de Mani, corazón de la misión franciscana en Yucatán. En 1562 participó en los interrogatorios de los indios en la provincia Hocaba-Homun, donde se habian descubierto prácticas de idolatría secretas. El asunto cuestionaba una vez más el problema de las conversiones superficiales. Una crueldad terrible caracterizó la actitud de los franciscanos al tratar de descubrir estas complicidades. Presuntos culpables se vieron torturados brutalmente. Las investigaciones de Bruselas y sus compañeros en las otras provincias de la península concluirian al final en un auto de fe aun antes de la fundación de la Inquisición en Méjico.

El sistema de reclutamiento de los dominicos y agustinos, que estaban presentes en América desde 1526 y 1543 respectivamente, impedía en general que frailes no españoles encontrasen el camino a América. En el caso de los franciscanos bastaba el permiso del vicario general y del guardián del convento de Sevilla. Los dominicos y agustinos necesitaban además la aprobación de sus vicarios provinciales. Los pocos dominicos y agustinos extranjeros que viajaban a América, habían profesado casi todos en España o ya habían vivido durante largo tiempo en la Península antes de tomar el hábito. La cédula real de septiembre de 1530 , que prohibió el paso de religiosos extranjeros a Indias, dificultaba aún más la travesía.

Nicolás de Witte, más conocido como Ubite, según la tradición también pariente del emperador, nació probablemente en Bruselas. De él se cuenta que estaba a punto de casarse en Burgos con una hija de una familia noble importante, sin embargo dejó a su novia sola en la iglesia para ingresar en el convento de los agustinos. En 1543 se fue a Nueva España, donde trabajaba con los Chichimecas y Huastecas, pueblos bárbaros que él comparaba con la nobleza en Italia, siempre en busca de aliados, declarando la guerra ora a esta tribu, ora a la otra. Se dedicaba sobre todo a la enseñanza acentuando siempre el conocimiento de idiomas. Al mismo tiempo se manifestaba como defensor de los indios, por lo cual le pusieron el apodo de "el noco", nuestro "amigo" o "compañero". Era sin duda el misionero más lascasiano de todos, más que Gante. En varias cartas, entre otras al Consejo de Indias y a Las Casas, atacó el sistema colonial vigente que imponía a los indios demasiadas obligaciones financieras. Propuso un restringido tributo, a fijar de antemano, que se repartiría entre la Iglesia, los encomenderos y el rey. De esta forma pensaba terminar la 
explotación arbitraria de los indios, que se veían obligados a andar de pueblo en pueblo para eludir las represalías por falta de pago.

Ubite era enemigo declarado de los diezmos, en primer lugar porque aumentaban la presión fiscal, pero también porque "estos indios son muy delicados, pensarán luego que vendemos los sacramentos". Reprochaba a los obispos por actuar muy enérgicamente en el cobro de sus impuestos.

“Y ya los obispos cá más pretenden tener que enseñar, puestos en pompa y en lo demás. Gran yerro se hace allá (en Madrid) en proveer obispos de allá, que no conozcan ni sepan la lengua destos miserables, ni sepan ni conozcan sus miserías cómo los pueden ayudar ni enseñar, sino ir al hilo de los españoles, como hace el arzobispo».

En su opinión, el obispo ideal debería desvivirse por sus indios, en vez de dedicarse únicamente a su propio interés y al de sus parientes. Escribió al emperador qué tipo de hombres podrían ser útiles en las colonias: que no mande

«mozos por casar y recién sacados del estudio, sino viejos y muy experimentados y afamados, que el mozo que viene acá no quiere sino agradar al común para hallar mejor casamiento y después de casados acá están rodeados de sus parientes, de sus mujeres. Como quiere Vuestra Majestad que el pobre indio desnudo alcance su justicia».

Su lenguaje claro puso a Ubite en conflicto con el clero secular y los funcionarios reales de Nueva España. Sus adversarios no dejaban pasar las ocasiones para desacreditarle ante el Consejo de Indias. Los ataques apenas le afectaban. Compañeros de la orden en Méjico y España defendían su trabajo, así que la maledición no tuvo nunca consecuencias graves para el flamenco. Ubite trabajó durante diez años más en Meztitlán. Murió el 21 de octubre de 1565 en Chilapa, donde era prior del convento de agustinos.

Cornelio de Bie nació el 10 de noviembre de 1540 en La Haya. De joven viajó a la península lbérica, donde profesó en 1559 en el convento de los agustinos de Granada para salir el mismo año a Nueva España. Se le mandó a Meztitlán, donde se juntó con Nicolás de Witte, dedicándose en primera instancia al estudio del idioma local. Pronto evolucionó como predicador hábil y logró convertir a gran cantidad de indios. En 1563 participó con Ubite en el Capítulo Provincial en Pasayuca. Después se dirigió a Chapulvacar, donde varias tribus belicosas dificultaron el trabajo de los misioneros. Logró convertirlos. En los años ochenta, los conventos de la región le mandaron como su procurador a Roma. En 1602 
el general de los agustinos le nombró visitador de las provincias de Escocia, Inglaterra y Holanda. Después de una larga carrera religiosa en los Países Bajos, murió en Bruselas el 26 de julio de 1614. De Bie es el único de los misioneros flamencos que volvió a Europa. Queda un enigma: por qué no hizo la travesía a América por segunda vez cuando su tarea de procurador terminó, sino que se quedó en Europa y prefirió una carrera eclesiástica predecible según el patrón clásico de la Iglesia europea. Quizás tenga que ver con sus problemas con la Inquisición de Méjico en lo que respecta a su atención extremada a las mujeres.

\section{UN SEGUNDO PEDRO DE GANTE}

Después de la conquista del imperio de los Incas por Pizarro en 1531 , fueron otra vez dos flamencos quienes sentaron las bases para la cristinización del reino de Perú: Pieter Gossael y sobre todo Joost de Rijcke, más conocido como Jodoco de Ricke. Este último nació en 1498 en Malinas. Era hijo del montero mayor del duque de Brabante. Su madre pertenecía a la familia noble de los Van Marselaer. Ricke profesó alrededor de 1515 en el convento de los franciscanos de Gante. Allí conoció a Pedro de Gante. Probablemente, leyó la carta que éste mandó en 1529 a los frailes de su orden en los Países Bajos, describiendo su trabajo en Texcoco. Poco a poco le surgía la idea de seguir el ejemplo de su ilustre compañero. En abril de 1532 se dirigió a Toulouse, donde se celebró aquel año el Capítulo General de la orden. Uno de los temas a tratar fue el pedido de los españoles para enviar a más misioneros al Nuevo Mundo. El Capítulo General decidió destinarle a Nueva España. Ricke salió para Sevilla, no sin antes escribir rápidamente una carta de despedida a sus padres.

"Les ruego cariñosamente, mi querido padre y madre, me disculpen que haya salido. Espero que nos veamos en la otra vida, y aunque mi cuerpo esté lejos de ustedes, mi corazón siempre estará con vosotros".

Justificó su decisión diciendo que la vida era demasiado corta para perder tiempo y que al fin había encontrado su vocación para servir a Dios y salvar su alma. En una carta de 1538, escrita desde Quito, se refiere nuevamente al tema de haberse marchado sin hablar primero con su familia:

"Habéis comprendido y admirado mi decisión de viajar al Capítulo General de Toulouse, fuera de su vista, fuera de mi patria y lejos de mis amigos, en este lugar pagano tan lejos y desconocido". 
En el otoño de 1533 Ricke salió del puerto de Sevilla para desembarcar tres meses después, el 19 de diciembre, en Hispaniola. Allí le dijeron que no le iban a destinar a Nueva España, sino a Nicaragua, a cuya provincia pertenecia Perú. Dos meses después se embarcó hacia la ciudad de Nombre de Dios en la costa panameña. En su compañía viajaron Pieter Gossael, un franciscano de Lovaina que había profesado en Brujas, Simón de Bruselas y Jan de Clerck del convento de Gante. No se sabe si el viaje lo hicieron juntos desde Sevilla o desde Santo Domingo. Cruzaron el istmo de Panamá y subieron a bordo de una de las naos que viajaba al Perú en busca de oro. Vientos contrarios y falta de víveres les llevaron a la altura de la isla Chira, en el golfo de Nicoya. Los flamencos se dirigieron al interior del país, a Granada y León, donde encontraron en el convento de los franciscanos al último fraile francés superviviente. En marzo Ricke y Bruselas continuaron su viaje en dirección hacia Perú. Aparentemente, Gossael y de Clerck se quedaron en Nicaragua. Ambos hombres siguieron al grupo de franciscanos de Marcos de Niza. Sin embargo, encontrándose en Tumbes, Bruselas volvió. Ricke siguió el camino del Inca al norte y entró como primer franciscano en la ciudad de Quito, en donde la población autóctona le recibió pacíficamente.

Como Gante en Méjico, Ricke se encontró en Quito con una sociedad desequilibrada, y además se vio castigado por aventureros sin escrúpulos en búsqueda de oro. El flamenco anotó irónicamente que "por el oro se descubre mucha tierra que de otra suerte quedase desconocida, y se salvan muchas almas que de otra suerte no llegasen a la salud eterna».

Ricke se dedicó inmediatamente al estudio del idioma local. El 25 de enero de 1536 empezó la construcción de un convento enorme que sería el centro de la misión franciscana en Perú. Tres años después los franciscanos habian erigido ya veintiocho conventos que se organizaron en una custodia de la cual Ricke fue el primer custodio. Gossael fue el primer guardián del convento de Quito. Se ignora cuándo había llegado allá. En su carta a los franciscanos de Flandes de 1536, Ricke aún no menciona a Gossael.

En el convento los niños indígenas recibían enseñanza no sólo en su propia lengua sino también en español. En 1536 Ricke aconsejó a futuros misioneros flamencos que fueran al Perú y que aprendiesen bien el español. Las actividades de Gante en Méjico pueden haberle inspirado la creación de su plan de estudios, porque Ricke no se limitaba sólo a enseñar a leer y escribir. Como Gante, enseñó a sus alumnos no sólo cómo tocar música sino también cómo arar con yunta. Sin embargo, fue en la enseñanza donde se nota la diferencia entre Ricke y Gante. Éste esperó hasta tener 30 ó 35 años para ingresar en el convento $y$, según se puede 
deducir de los cursos que enseñaba en su escuela, su juventud la aprovechó para capacitarse en varios oficios. Ricke profesó siendo aún joven y $\sin$ experiencia en trabajos manuales. Su ascendencia noble no lo hubiera permitido. Se interesaba por las adivinaciones de los indios y siempre prestaba mucha atención a sus prácticas supersticiosas. En 1565 un tal Pedro de Sarmiento tuvo problemas con la Inquisición por llevar varios «anillos de suerte» que Ricke había fabricado.

Aparte de la enseñanza, Ricke probó también un método que ya en las Antillas había resultado eficaz. En su Historia del Mondo Nuovo, Girolamo Benzoni, que se había topado con Ricke en Quito en los años cuarenta, describe cómo el franciscano viajó en un momento dado a Cañares para erigir un convento. Invitó a todos los jefes de tribu de la región, pero sólo tres aceptaron su invitación. Les persuadió a convertirse y los jefes volvieron como cristianos a casa. Cuando Ricke notó que dejaban de venir a misa, les recordó sus buenas intenciones, y ellos le contestaron que tenían cosas mejores que hacer que ir a misa, lo que le impulsó a abandonar sus intentos y volver a Quito. Ricke calificaba a los indios de Perú como gente que aceptaba fácilmente la fe católica, pero que renegaba de ella con la misma facilidad. Se necesitaba una predicación continua para impedir que volviesen a su antigua fe. En este aspectos las dificultades con las cuales Ricke se veía confrontado se diferenciaban con las de los flamencos en Nueva España.

Por último, también Ricke deploraba la avaricia de los conquistadores españoles que impedía la conversión de los indios. Sin embargo, en la rebelión de Pizarro de 1544 a 1548, Ricke habría estado en primera instancia al lado del rebelde. Los datos de este período son tan escasos que por el momento es imposible determinar su posición en el conflicto.

Durante todos estos años en Quito, Ricke hacía muchos esfuerzos para mantener los lazos con la patria. De todos los misioneros flamencos, Ricke fue el que escribió más cartas. En 1536 dio indicaciones a sus corresponsales de cómo mandar sus cartas para que le llegaran a Quito. Sólo dos años después se conformó con la idea, en una carta enviada a sus padres, de que nunca más iba a verles. En 1564 permitió que lo inscribieran en el Liber defunctorum del convento de Gante. Algunos ven en este acto la ruptura definitiva con su patria, pero también podría significar una precaución para impedir que su patria le olvidase. El 2 de agosto de 1578 Ricke murió en el convento de Popayán que él mismo había erigido, alcanzando la edad de ochenta años, como era curiosamente el caso de muchos misioneros en la América del siglo XVI. 


\section{PIONEROS}

A partir de la mitad del siglo XVI surgieron problemas en buena parte de los núcleos misioneros por falta de éstos. La primera generación de frailes estaba desapareciendo poco a poco y los refuerzos que venian de Europa no podían llenar los huecos. Puestos de evangelización periféricos se abandonaron o sus actividades se limitaron. Por tanto, la llegada de los jesuitas en 1572 significó un nuevo impulso. Los primeros jesuitas flamencos no hicieron la travesía al Nuevo Mundo hasta inicios del siglo XVII. La mayoría se dirigió a las reducciones de América del Sur. En el siglo Xvı sólo he podido encontrar a Jerónimo Goethals, que murió en 1594 en Méjico. No se sabe más de él.

Contemplando las actividades de los misioneros flamencos en Hispanoamérica en el siglo XVI, salta a la vista sobre todo una característica: fueron en general new frontier men. De la Deule y Cosin, Gante y sus compañeros, De Bie, Ricke, todos siguieron las huellas de los conquistadores penetrando en un terreno desconocido para sentar las bases de la evangelización de la región. Esbozaron los grandes rasgos del método misionero que luego fue adaptado por otros misioneros. En esto dieron pruebas de mucho sentido de la realidad y justificaron sus actos frente a sus compañeros españoles y el gobierno en Madrid. Tuvieron la ventaja de que no debían lealtad a los españoles y muchas veces sólo se sintieron vinculados a la persona del emperador. Se sirvieron de su posición independiente para defender a los indios ante las instancias más importantes y esto lo hicieron de una manera audaz y sin complejos. Pocos elementos indican una colaboración intensa y continua con sus compañeros españoles. Se atenían a los convenios establecidos, pero aparentemente preferían trabajar con independencia.

Su trabajo de conversión se vio influido por las ideas erasmistas en cuanto a humanidad y comprensión. Las bases de su método eran la predicación y la enseñanza, no la espada. Sin embargo, uno puede preguntarse si el presunto respeto para la cultura india, que se expresaba en su respeto hacia los idiomas indígenas, fue una consecuencia de sus ideas erasmistas o simplemente resultado de consideraciones prácticas. Quizás respeto no es una buena palabra en este contexto. Su comportamiento se caracterizaba por un paternalismo explícito, que por antonomasia excluía cualquier forma de respeto para las opiniones del otro. Respeto implica que se deje al otro en sus opiniones si él lo prefiere. En este sentido, hablar de respeto en el marco de los movimientos misioneros del pasado siempre será un anacronismo y por tanto inoportuno. Imponer su propia religión, no importa de qué manera, siempre excluye cualquier forma de respeto. Se puede concluir, a lo más, que los flamencos, y sus 
compañeros españoles, mostraban respeto al indio como posible cristiano, pero no por su postura vital o por sus ideas.

Tampoco era muy eramista el uso de la violencia en la conversión de los indios. Los flamencos no se sirvieron de la violencia física a la persona del indio, pero fueron a los pueblos para destruir templos e imágenes indígenas. Esta actitud era contraria a la visión de Erasmo sobre la evangelización, que se basaba en la persuasión del otro con razones con el fin de hacerle entender por su propia voluntad que erraba. La destrucción de la base material de las religiones indígenas, al contrario, excluía cualquier alternativa al catolicismo. En este sentido De Rijcke fue tal vez el misionero más erasmista de todos.

Otros autores, entre ellos Weckmann, destacan la influencia de la Devotio Moderna sobre el trabajo de los flamencos. Sin embargo, con el material del que disponemos por el momento, es muy prematuro formarse un juicio completo de las actividades de los misioneros flamencos. Demasiadas preguntas siguen sin respuesta. De ninguno de ellos se sabe algo de su juventud, sus orígenes, sus motivaciones. Solamente de Gante se ha podido reconstruir de manera más o menos completa su método misionero y sus actividades en Nueva España. El status quaestionis de la investigación histórica, sin embargo, permite formular cautelosamente la siguiente hipótesis: aunque los misioneros flamencos no fueron numerosos en América Latina, desempeñaron un papel importantísimo en la evangelización del continente y en la construcción de una cultura colonial. Nuevas investigaciones deberán profundizar más esta hipótesis.

\section{BIBLIOGRAFÍA}

La evangelización de América constituye el tema principal de los estudios de RICARD, R., La "Conquête spirituelle" du Mexique. París 1933; GruzınSKI, S., La colonisation de l'imaginaire. París 1988; Borges, P., Métodos misionales en la cristianización de América: siglo XVI. Madrid 1960; Baudot, G., Utopie et histoire au Mexique. Tolosa 1976; Liss, P. K., Mexico under Spain 1521-1556. Chicago-Londres 1975.

Varios autores dedican unas páginas al papel de los misioneros flamencos: Griffin, J. A., The Contribution of Belgium to the Catholic Church in America (1523-1857). Washington 1932; Olbrechts, F., Vlaanderen zendt zijn zonen uit. Lovaina 1942; Galerie Missionnaire Franciscaine Belge. Malinas 1926; PAzos, M.R., Misionología Mejicana. Lingüistas y poliglotas franciscanos. Tánger 1962; ASPURZ, L. DE, La aportación extranjera a las misiones españolas del Patronato Regio. Madrid 1944; Idem, “Despertar misionero en la Orden franciscana en la época de los descubrimientos (1493-1530)», Estudios franciscanos, núm. 50 (1949), págs. 415-438; Idem, “La idea misional fuera de la Península Ibérica en los siglos XVI y XVI'”, Archivo Ibero-Americano, núm. 1 (1944), págs. 495-515; Actas de I Congreso Internacional sobre los Franciscanos en el Nuevo Mundo. Madrid 1986; Actas del II Congreso Internacional sobre los Franciscanos en el Nuevo Mundo. Madrid 1988.

La política colonial de Carlos V se analiza en BATAILLON, M., Études sur Bartolomé de las Casas. París 1975, sobre todo el capítulo "La Cour découvre le Nouveau Monde"; CASTRO, M., 
"Adriano de Utrecht y el gobierno de las Indias", Archivo Iberico-Americano, núm. 116 (1969), págs. $345-380$.

Se encuentra información biográfica sobre De la Deule y Cosin en LIPPENS, H., «Fr. loanne de la Deule missionario Americae (1493-1510)", Archivum Franciscanum Historicum, núm. 27 (1934), págs. 62-75. TAOEYER, B. de, dedicó un estupendo artículo biográfico a Glapion en su Bio-bibliographica franciscana neerlandisca saeculixvı, vol. I. Nieuwkoop 1969, págs. 5560 , y en el Nieuw Biografisch Woordenboek, vol. VI. Bruselas 1974, págs. 347-353. En el mismo tomo de la Bio-bibliographica, págs. $75-83$, se incluye una bibliografía amplia sobre Pedro de Gante. Las cartas de Gante se publicaron en TORRE VILLAR, E. de la, Fray Pedro de Gante: maestro y civilizador de América. Méjico 1973. Las cartas de Nicolás de Witte se publicaron en Cuevas, M., Documentos inéditos del siglo xvi para la historia de México. Méjico 1914. Cornelio de Bie aparece en CuRtius, C., Virorum illustrium ex ordine eremitarum Sancti Augustini. Amberes 1636; Elssius, P., Encomiasticon Augustinianum. Bruselas 1654; SANTIAGo VelA, G. de, Ensayo de una biblioteca Ibero-Americana de la orden de San Agustín vol. I. Madrid 1913. De Bie publicó sus sermones en Sermones dominicales. Amberes 1605.

Sobre Jodoco de Ricke: PAEPE, C. de, en Franciscana, núm. 33/1 (1978), págs. 3-22; núm. 33/ 2 (1978), págs. 71-86; núm. 34/1 (1979), págs. 3-19; núm. 37 (1982), págs. 135-151; Idem, "Een merkwaardig stuk uit het Leuvens universitair archief: het Zuidamerikaanse reisverslag van broeder J. de Rijcke (1533-1536)", Onze Alma Mater, núm. 25/4 (1981), págs. 255-278. 